\title{
Factors Affecting the Use of Andragogical Principles in Adult Education Programs in Lagos State, Nigeria
}

\author{
Tewo V. Bakare \\ ${ }^{1}$ Department of Adult Education University of Lagos. Lagos. Nigeria. \\ Email: tbakare@unilag.edu.ng
}

\begin{abstract}
The argument that adults deserve to be treated differently in the teaching/learning milieu has been brought to the forefront by many researchers and adult educators, spearheaded by Malcolm Knowles' notion of andragogy. Knowles asserted that adults require certain conditions to learn. Generally, literature has also supported the idea that teaching adults should be approached differently from that of adolescents. There are several adult education programs in the Lagos State of Nigeria. This study examined the level of awareness of, and factors that affect the use of andragogical principles in these programs; facilitators and learners' perception of their roles in teaching/learning, as well as method used. Some 361 participants from six different Adult Education programs and 132 facilitators were used for the study. Interviews and Sit-in-observations, together with the questionnaire, were used to gather data. Chi-squared statistical analysis revealed that facilitators were mostly aware of, but did not make use of andragogical principles in helping adults to learn due to several factors. Suggestions made for improvement include that appropriate training for adult educators be encouraged, as well as expanded use of technology to facilitate adult learning towards national development.
\end{abstract}

Keywords: Andragogical Principles; Development; Methods; Adult Education Programs; Technology; Lagos State Nigeria.

Citation: T.V. Bakare (Ph.D). Factors Affecting the Use of Andragogical Principles in Adult Education Programs in Lagos State, Nigeria 2019; 4(1): 23-34.

Received: January 2, 2019

Accepted: June23, 2019 


\subsection{Introduction}

The way adults are treated in the process of teaching/learning affects the learning process, and if adults, who form the more productive sector of the economy, are to benefit from all forms of education, it is important to pay attention to this process. Andragogy as a principle and theory has been widely prescribed as an approach to adult teaching/learning, predicated on certain factors. As lifelong learners, it is imperative that adults constantly update their knowledge to adapt and fit into the noughties in order to cope with the new technological age. This study explored the factors affecting the application of adult education principles in programs within Lagos state, Nigeria.

\subsection{Literature Review}

The need to pay special attention to adult learners and to adult education as a field gained impetus after several International Conferences suggested that adult education be a separate discipline and that adult learners be treated differently from child learners because they learn differently (Noe, 2010; Robertson, 2005; Ray and Hui-Chin, 2005). Prior to this, education of both adult and child learners were viewed globally in terms of general and formal education. Adult education had fallen victim of teacher-centred models of teaching, along the same lines with child education, until the late 1920s when rigorous research started in America on better ways to help adults learn. The world is dynamic; the what, when, where and how of learning were changing, therefore adult education methods must also change with the times in order to continue to satisfy the needs of its clientele. Since adults form a large group of learners in most societies (Altbach, Berdahl, \& Gumport, 2005), it is imperative to highlight the efficacy of andragogy as the hitherto, most embraced model of adult learning. When adult education as a field, first became popular in the early 1900s, the assumption was that the same methods and techniques used to teach pre-adolescents and children would also be applicable to adult learners. Knowles, in his pioneering role in the field of andragogy, drew immeasurable attention to the new idea that adults should be approached differently in teaching/learning. He believes strongly that adult learning programs need to accommodate the fundamental concept that adult learners are self-directing and take responsibility for their learning. Researches over time have equally shown that, in order to teach adults successfully, several factors must be considered including those methods and techniques which must be adapted to their needs, and the incorporation of audio-visual aids to show a distinct advantage over the use of traditional education techniques (Brunner, 2000). Adult learners do not, as yet, seem to be benefitting from these precepts in Nigeria. 


\subsection{Andragogical Principles}

It has often been argued that if indeed adults differ from children, then they should be taught differently (Gaetano, 2016). The idea that adults learn differently from young people has been proclaimed over the years. Malcolm Knowles explains that adult learners are volunteers who no longer need compulsory formal education, and therefore are self-motivated for their own learning activities. These ideas are encapsulated in Knowles' ideology of andragogy, and reiterated in later works by Imel (1998) and Conner (1997), among others. Ray and Hui-Chin (2005) further assert that adults are usually not interested in learning for learning sake (which may occur in formal education). Most adult learners in Nigeria today are still reeling from age-old teacher-reliant techniques of colonial times and are learning to be more inquisitive and selfdirecting in their education (Osuji, 2004). Knowles used andragogy synonymously with adult education and adult learning, as different from pedagogy: the child-focused teaching approach.

Andragogy is multifaceted in application. It is a theory of adult learning; adult education technology; a method and technique of adult education, a principle, as well as a set of assumptions. Andragogy is the Art and Science of helping adults to learn according to its progeny Knowles (1984) who describes it as a body of theory, process and technology, and echoed by Kearsley (2010). Knowles' idea is supported in later works by Ray and Hui-Chin (2005); Brookfield, 1992, and Corder (2002). Andragogy is also seen as a method in adult education where several factors are considered including method use, availability of teaching aids and facilitator's qualification.

Andragogy is recommended for adult learners, using learner-centred methods. The tenets are that adults have a wealth of experience accumulated over the years and would learn better if their life experience were factored into the teaching/learning situation. The approach to learning also shifts in that the adult becomes increasingly self-directing; they learn for immediate rather than delayed use like children; Adult learners need to be able to connect learning to their own goals and progress; Their readiness to learn is influenced by their problem-centred orientation to learning; They also need to be given more time and opportunity to reflect on new learning in order to internalize and retain new information; they are internally motivated, focused and ready to take responsibility for their learning. These factors mean that different methods must be used in helping adults to learn to accommodate different learning styles; but those methods must favour group activities, as well as experiential and practical methods of learning. Applying andragogical principles would then translate into tackling learning from known to the unknown - simple to complex; going according to the learner's pace; giving adequate consideration to their deteriorating senses, and making 
allowances for their social responsibilities - but ultimately, treating them with respect. The adult learners' innate fears and self-concept equally need to be addressed - the fear of being ridiculed, fear of failure, or not being able to actually learn, along with other anxieties. Thus it becomes imperative for the adult educator to encourage adult learners always; to put their minds at rest and give them assurance of the possibilities of learning. Fidishun (2006) adds that technology must be used to its fullest to facilitate the use of andragogy while teaching as it encourages flexibility for the learning adult to fit learning into his busy schedule, as he can then learn anywhere, anytime, and at his own pace, which further encourages his self-directing tendencies. Previous critics' dichotomous position has been modified in favour of regarding andragogy ultimately as good principle of practice in teaching/learning for both adult and child learners. Most adult education programs organized in Lagos State can be subsumed under these five broad categories according to Bakare (2013). 1. Literacy (Initial and Post), 2. Continuing (Further, or Remedial), 3. Vocational, 4. Fundamental/Foundation, and 5. Leisure/Liberal Education. This research is guided by the assertion that adults should be treated differently in teaching/learning and andragogical principles employed. It is premised on the belief that adults form the majority of learners, and constitute the labour force, thus not considering the best circumstances for their learning would be detrimental to national development aspirations. This study examined how adult education programs are handled in Lagos State of Nigeria, specifically whether facilitators are aware of and apply andragogical principles and methods in practice, along with the mitigating factors. The study treated five research questions and tested two hypotheses.

\subsection{Research Methodology}

The method is empirical and survey in nature. Respondents were selected from the five types of adult education programs in Lagos State Ministry of Education (LSME). The programs cut across the 20 officially recognized Local Government Areas (LGAs) of the State. Six programs accredited by the LSME's Adult and Non-Formal Education Department formed the basis of the sample selection process. LSME records showed 1318 centres with an estimated 5850 adult learners for the programs examined in this study. Some 361 participants were proportionately and randomly selected as the sample, along with 132 facilitators from each of the programs. Table 1 below shows the sampling procedure.

Table 1: Sampling Procedure

\begin{tabular}{lllll}
\hline $\begin{array}{l}\text { Program } \\
\text { Type of Education }\end{array}$ & $\begin{array}{l}\text { No of } \\
\text { centres }\end{array}$ & $\begin{array}{l}\text { No of learners } \\
\text { in program }\end{array}$ & $\begin{array}{l}\text { No of learners } \\
\text { selected }\end{array}$ & $\begin{array}{l}\text { No of facilitators } \\
\text { selected }\end{array}$ \\
\hline Initial Literacy & 720 & 1100 & 68 & 25 \\
\hline
\end{tabular}




\begin{tabular}{lcccc}
\hline Post Literacy & 103 & 250 & 15 & 5 \\
Remedial & 134 & 950 & 59 & 22 \\
Vocational & 120 & 1100 & 72 & 25 \\
Fundamental & 178 & 1200 & 73 & 27 \\
Leisure & 63 & 1250 & 74 & 28 \\
\multicolumn{1}{c}{ Total } & 1318 & 5850 & 361 & 132 \\
& & Grand Total & & 493 \\
\hline
\end{tabular}

From Lagos State Ministry of Education records (2000)

Three instruments were used for the study. The Questionnaire was used to collect information from the participants, along with an Interview schedule, combined with Sit-in Observation of the different programs. The three instruments were validated by three experts in the field of Adult Education. A pilot study using the Alpha Crombach analysis of the instruments yielded the following results after a three-week interval test-retests - Questionnaires - .76 (facilitators) and .79 (learners); Interviews .72 and the Sit-in Observation .84), rendering them usable for the study. The Sit-In Observation Schedule was developed to help rate individual programs and observe the application of factors of andragogical principles based on the following indices: method observed being used, compared with what the facilitator claims to be using; facilitator's attitude, and learner's demeanour and participation level, as well as the use of teaching aids and technology. These were rated between 1 and 5 with 5 being the highest according to the researcher's observation and recorded. These ratings were to establish factors influencing the use or non-incorporation of andragogical principles into the teaching/learning process. The checklist was also tested against facilitators training background, along with the availability of, and use of teaching aids and technology. Subsequently, two hypotheses were tested; that professional training in adult education will not significantly influence the use of andragogical principles in adult education programs, and that the availability of teaching aids will not significantly influence the use of andragogical principles in adult education programs.

\subsection{Results presentation}

Some factors were found to affect the use of andragogical principles in the programs - facilitator training, choice of teaching method, availability of facilities and the use of teaching aids. As indicated in table 2 below, facilitators in the 132 selected programs were mostly untrained specifically to work with adult learners. 
Table 2: Facilitators qualification

\begin{tabular}{|c|c|c|}
\hline Educational qualification & Number & $\%$ \\
\hline Primary & 7 & 5.3 \\
\hline Secondary & 32 & 24.2 \\
\hline NCE/TECH & 35 & 26.5 \\
\hline Professional & 19 & 14.4 \\
\hline University & 28 & 21.2 \\
\hline Post Graduate & 11 & 8.4 \\
\hline Total & 132 & 100 \\
\hline
\end{tabular}

Table 2 shows that, although many of the facilitators had certificates, the majority $91(68.9 \%)$ had them in other disciplines, but not in education, and specifically not in adult education (only 2 of the respondents claimed to have Adult Education certificate). This suggests that most of the facilitators were not appropriately trained or equipped to help adults to learn. The handling of the teaching/learning situation was thus found to be low in andragogical content in the adult education programs observed. Up to 118 $(89.40 \%)$ of the facilitators admitted that they were not trained specifically as adult educators. Training is often reflective of the other indices like method choice, resourceful use of teaching aid, and the approach to the teaching/learning experience. Facilitator's training background was thus found to be a contributory factor in the use of andragogical principles.

Figure 1 below shows the results of the Sit-in observation by programs evaluating whether practitioners were applying andragogical principles. The result showed a minimal application of andragogical principles with less than half of the Center's activities not indicating the practice of andragogical principles.

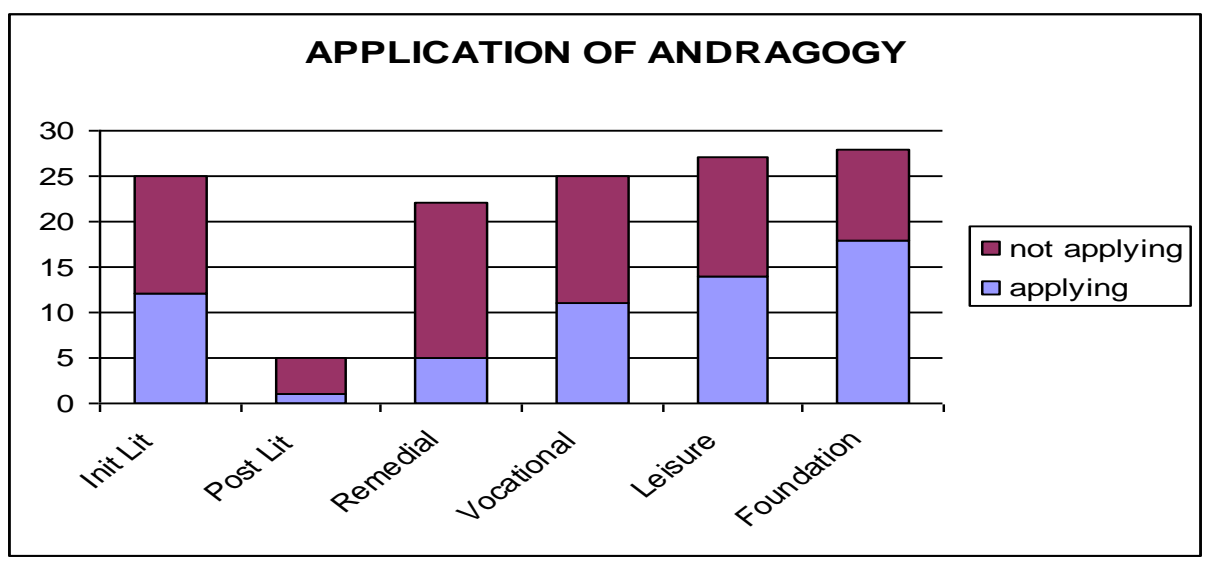

Figure 1: Application of Andragogical Principles in the Adult Education Programs 
The interview directed at the learners revealed in part, that most of the learners viewed the adult educator as the teacher and authoritative figure. Responses also revealed that learners still see teachers in the same light as from their previous experience in formal education. Choice of method was dependent on the topic as well as the availability of teaching material. Observation also revealed that most of the methods used were non-participatory and rather teacher-centred (popular methods used as indicated in fig. 2).
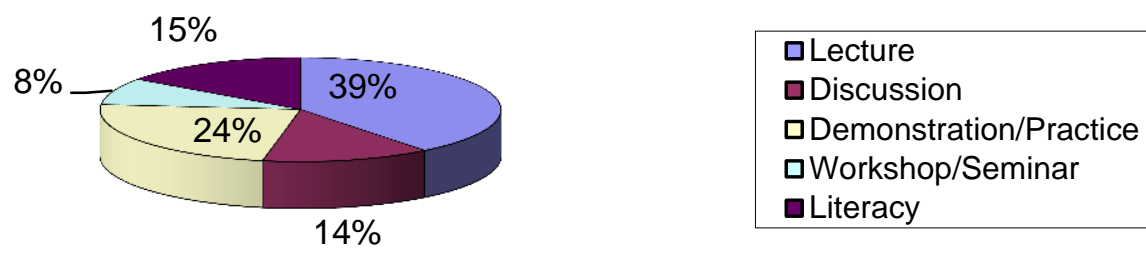

Figure 2: Popular Methods used in the Programs

Contrary to the dictates of andragogy which encourage the use of more Participatory Methods, majority $(55.3 \%)$ of the facilitators utilized the Straight Lecture Method most of the time. This also implies that the experience of the adult learner is not being incorporated into the teaching/learning activities, which does not encourage self-directedness in the adult learner. Furthermore, there was low availability level of teaching materials and scant technology to enrich the teaching-learning experience in the programs.

Level of availability of teaching aids in the Institutions

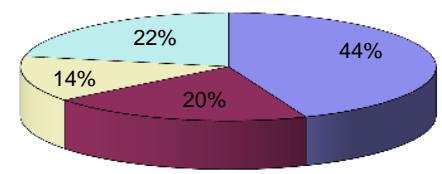

口Basic $\quad$ aSome $\quad$ aAll 口Others

Figure 3: Availability of Teaching Aids in the Programs

Key to Figure $3 \quad$ Teaching Aids




\begin{tabular}{llll}
\hline BASIC & Blackboard and chalk only & 1. Blackboard and chalk \\
SOME & A few of the teaching aids, between 2- 4 & 2. Television and Video, Tape Recorder \\
& of the items listed to the right & 3. Flip Charts and Magic Board \\
ALL & All of the teaching aids listed & 4. Projectors (overhead, slide, etc.) \\
OTHERS & Such aids for examples as seedlings for & 5. Computers and Typewriters \\
& $\begin{array}{lll}\text { demonstration in the Farmers' Program } & \text { 6. Public Address System, etc. } \\
& \text { in Agricultural Extension Education, } & \text { 7. Transparencies } \\
& \text { etc. } & \text { 8. Others }\end{array}$
\end{tabular}

Figure 3 indicates that most of the institutions have only the basics 58 (43.9\%) and $26(19.7 \%)$ have some. This suggests that majority are operating below standards of good practice, and that teaching aids (especially technology) are not utilized enough to enrich the teaching/learning experience. This does not augur well for the practice of adult education and does not agree with the tenets of andragogy that technology is incorporated in adult education programs as often as possible. Training background reflects in the choice of method and use of teaching aids and is also a factor.

\subsection{Test of bypotheses}

In the study, two hypotheses were tested using the chi-square tool. The first hypothesis targeted facilitators and sought to establish the link between facilitators' qualification and their use of andragogical principles in teaching/learning.

Table 3: Influence of professional qualification on the application of andragogy

\begin{tabular}{|c|c|c|c|c|c|}
\hline \multirow{2}{*}{$\begin{array}{l}\text { PROFESSIONAL } \\
\text { EDUCATION } \\
\text { QUALIFICATION }\end{array}$} & \multicolumn{2}{|c|}{$\begin{array}{l}\text { APPLICATION OF } \\
\text { ANDRAGOGY }\end{array}$} & & \multirow[t]{2}{*}{$\begin{array}{l}\mathrm{X}^{2} \\
\text { calc }\end{array}$} & \multirow[t]{2}{*}{$\begin{array}{l}\mathrm{X}^{2} \\
\text { crit }\end{array}$} \\
\hline & YES & NO & Total & & \\
\hline NCE/TT & $16(9.71)$ & $5(11.29)$ & 21 & & \\
\hline TECHNICAL & $12(7.86)$ & $5(9.14)$ & 17 & & \\
\hline DEGREE/PG & $14(8.78)$ & $5(10.22)$ & 19 & & \\
\hline DEGREE/DIP IN ADE & $2(0.92)$ & $0(1.07)$ & 2 & & \\
\hline $\begin{array}{l}\text { SHORT INDUCTION } \\
\text { COURSE IN ADULT } \\
\text { EDUCATION }\end{array}$ & $15(7.39)$ & $1(8.61)$ & 16 & 80.72 & 11.07 \\
\hline $\begin{array}{l}\text { NO PROFESSIONAL } \\
\text { TRAINING }\end{array}$ & $2(26.34)$ & $55(30.66)$ & 57 & & \\
\hline TOTAL & 61 & 71 & 132 & & \\
\hline
\end{tabular}

Df $=5 ; \quad$ Level of significance $=0.05 ; \quad \mathrm{X}^{2}$ calculated $=80.72 ; \quad \mathrm{X}^{2}$ critical table value $=11.07$ 
Table 3 shows a higher $\mathrm{X}^{2}$ calculated value (80.72) than the critical table value (11.07) at 0.05 level of significance and degree of freedom 5. The null hypothesis was therefore rejected, which suggests that the professional educational qualification of the facilitator could be positively associated with their application of andragogical principles in adult education programs; and that those with adult education and other professional training tended to use andragogical principles more. The indices connoting the engagement of andragogical principle are just as stated earlier; like class organization, level of teacher-input and learnerparticipation as well as the rapport between the facilitator and learner, which were all considered in the Participatory Class Observation.

Table 4: Influence of availability of teaching aid on the use of andragogical principles

\begin{tabular}{|c|c|c|c|c|c|}
\hline \multirow[t]{2}{*}{$\begin{array}{l}\text { Availability of } \\
\text { teaching aids }\end{array}$} & \multicolumn{2}{|c|}{$\begin{array}{l}\text { Application of } \\
\text { andragogical } \\
\text { principles in the program }\end{array}$} & \multirow[t]{2}{*}{ Total } & \multirow[t]{2}{*}{$\begin{array}{l}\mathrm{X}^{2} \\
\text { calc }\end{array}$} & \multirow[t]{2}{*}{$\begin{array}{c}\mathrm{X}^{2} \\
\text { critical }\end{array}$} \\
\hline & YES & NO & & & \\
\hline Basic items only & $11(28.12)$ & $47(29.88)$ & 58 & & \\
\hline Some items & $17(13.09)$ & $10(13.91)$ & 27 & & \\
\hline All & $14(8.72)$ & $4(9.27)$ & 18 & 41.13 & 12.59 \\
\hline \multirow[t]{2}{*}{ others } & $22(14.06)$ & 7 (14.94) & 29 & & \\
\hline & 64 & 68 & 132 & & \\
\hline $\begin{array}{l}\mathrm{X}^{2} \text { calculated }=41.13 \\
\text { Degree of freedom }=6 \\
\text { Level of significance }=\end{array}$ & $\begin{array}{l}\mathrm{X}^{2} \text { critical } \\
0.05\end{array}$ & $=12.59$ & & & \\
\hline
\end{tabular}

Table 4 showed a higher $\mathrm{X}^{2}$ calculated (41.13) than the critical $\mathrm{X}^{2}$ table value (12.59), at 0.05 level of significance and degree of freedom 6. The null hypothesis was thus rejected and the alternative adopted. This suggests that the availability of teaching aids significantly affects the use of andragogical principles in the programs.

Certain items were listed previously as possible teaching aids, ranging from the basic blackboard and chalk to more advanced technological materials. The table shows the relationship between the availability of teaching aids and the use of andragogical principles in helping adult learners. It was discovered that the provision of teaching aid from support agencies influenced the use of andragogical principles in the programs. The program also shows that the lowest available teaching aids were in those programs whose sponsors were the government, and they were largely only provided with the barest minimum of teaching 
aids - like the chalk and blackboard, which implies that they were possibly not considering the factor of possible deterioration of the senses of the adult learner. It must be added that facilitator's resourcefulness may also come into play in handling situations.

\subsection{Discussion of Findings}

The study showed the lack of appropriate training and exposure for facilitators generally, as they were most qualified to teach children (many do not have corresponding diplomas in teaching, and those who did were not specifically trained to work with adult learners); this is contrary to popular opinion (Corder, 2002; Gaetano, 2016; Bakare, 2013). The level of training in the field showed that facilitators with adult education training background tended to be better able to help adults to learn, in line with andragogical principles, than those who were not specifically trained in the field; or merely picked up ideas over years of experience (unfortunately, in most cases those experiences were limited to child learners), because their circumstances are different as supported by the proposition of Ray and Hui-Chin (2005), and according to the tenets of andragogy. Ultimately qualification was found not to be synonymous with competence.

The facilitators did not exhibit adequate exposure to the tenets of andragogy, which challenges Brookfield's (1992) assertion that the principles are vital to the teaching/learning encounter for adult learners. This also agrees with Bakare's (1999) observation concerning the lack of incorporation of andragogical principles into adult education programs by facilitators. This was partly demonstrated in the overwhelming use of the Lecture Method, which neither encourages self-directedness, nor taps from the adult's life experience, to make for successful adult learning.

Findings showed that both the facilitators and adult learners needed a re-orientation as to the role of the facilitator and the adult learner, and what is expected of them in teaching/learning. The study further revealed that adult learners were not necessarily treated differently from child learners as was observed during the Sit-in Observation schedule when the Learning Centers were visited. The implication is that adult learners were not being accorded necessary consideration as prescribed by Knowles' andragogy. Learners also still generally viewed adult educators as a figure to be revered and obeyed, which will obviously affect their interpersonal relations. This, unfortunately, will only encourage the facilitators to treat the learners like children who may be chastised and disciplined, and so not accord them due respect. Facilitator's training background as a factor would also partially account for the treatment of the adult learner.

The straight lecture method was found to be used across board in all the programs observed in Lagos, though more pronounced in some programs. Unfortunately, this method does not adhere to the principles 
of andragogy. Other militating factors for andragogy, apart from facilitator training, were found to be funding, establishment's support, availability of technical teaching aids, as well as the personality of the adult educator themselves. This again suggests that, if adult educators were not professionally trained, best choices may not be made (Bakare, 2013).

\subsection{Conclusion and Recommendations}

Many factors were found to be responsible for the low level of incorporation of andragogical principles into the programs, including lack of appropriate training of facilitators, poor choice of methods and little use of technology. There is consequently the need to encourage proper training of adult educators, rather than the usual umbrella assumption that anyone can be a teacher; appropriate methods and approaches must be used in helping adults to learn. It is recommended that the use of technological tools and devices like the basic computer must also be encouraged to make adult learning easier. It was established that it is imperative to treat adult learners with due respect and fully consider their peculiar circumstances if learning is truly to be effective. Adult learning through legitimate adult education methods is vital to national development as well as personal growth and in compliance with global standards.

\section{References}

1. Altbach, P., Berdahl, R., \& Gumport, P. (2005). American higher education in the twenty-first century, (2nd Ed.). Baltimore, MD: Johns Hopkins University Press. 
2. Bakare, T.V. (1999). Andragogy: An Assessment of the Application of Adult Education Methods in Lagos State. University of Lagos Ph.D Thesis (unpublished).

3. Bakare, T.V. (2013). Elements of Adult Teaching Methods. University of Lagos Press.

4. Brookfield, S.D. (1992). 'Why can't I get it right?' Myths and realities in Facilitating adult learning.San Francisco: Jossey Bass.

5. Brunner deS E. (2000). Methods and technique in adult education. Washington: Adult Education Association of the USA.

6. Conner, M. L. (1997). ‘Andragogy and Pedagogy’. Ageless learner. Texas: Creative Commons.

7. Corder, N. (2002). Learning to teach adults: An introduction. London: Routledge Farmer.

8. Fidishun, D. (2006) Andragogy and Technology: Integrating adult learning theory as we teach with technology. Malvern: Penn State Great Valley.

9. Gaetano, K. (2016). 5 ways adult learn differently than children. Corporate training, e-learning best practices, learning strategy. https://learnkit.com/2016/02/04/selecting-an-elearning-company/ 2/1/19.

10. Imel, S. (1998). Teaching adults - is it different? ERIC Digest no 82.

11. Kearsley, G. (2010). Andragogy (M.Knowles). The theory into practice database. Retrieved from http://tip.psychology.org.

12. Knowles, M. (1984) Andragogy in action: applying modern principles of Adult Learning. San Francisco: Jossey-Bass.

13. Noe, R. A. (2010). Employee training \& development (5th Ed.). NY: The McGraw-Hill Companies, Inc.

14. Osuji, S.N (2004). New perspectives in adult education in Nigeria in the twenty-first century. Online submission.

15. Ray, C.W. (Jnr) and Hui-Chin C. (2005). Does Andragogy work in Taiwan? An Analysis from Eastern Cultural Perspective. Online submission. Paper presented at the Academy of Human

16. Resource Development International (AHRD) Conference. Estes Park CO. Pp 101-108.

17. Robertson, D.N. (Jnr) (2005). Self-directed learning: past and present - Online Submission. 